\title{
EFEKTIVITAS BUKU AJAR BERBASIS HIGHER ORDER THINKING SKILLS (HOTS) PADA MATERI ELASTISITAS DAN HUKUM HOOKE SISWA KELAS XI SMA NEGERI TUGUMULYO TAHUN PELAJARAN 2018/2019.
}

\author{
Oleh: \\ Novitasari $^{1}$, Tri Ariani ${ }^{2}$, Yaspin Yolanda ${ }^{3}$ \\ ${ }^{1}$ Alumni Program Studi Pendidikan Fisika STKIP PGRI Lubuklinggau \\ ${ }^{2}$ Dosen Program Studi Pendidikan Fisika STKIP PGRI Lubuklinggau \\ ${ }^{3}$ Dosen Program Studi Pendidikan Fisika STKIP PGRI Lubuklinggau \\ Email: novitasari210896@gmail.com
}

\begin{abstract}
This study aims to determine the learning outcomes of class XI students in Tugumulyo State Senior High School 2018/2019 Academic Year after using the physics-based teaching material of elasticity and hooke's law and to find out the students response to learning using the higher order thinking skills approach to elasticity and hooke's law material of class XI students at Public High School Tugumulyo 2018/2019 Academic Year. The population of this study were all students of class XI and the subject of this study consisted of 34 students of class XI IPA 5 of State Senior High School Tugumulyo. Data collection is done by questionnaires, tests, and observations. The overall percentage of teaching material components was $79,24 \%$ (very good). The percentage of student responses to higher order thinking skills -based teaching materials is 76,53\% (very good). In addition, from the results of daily test tests, the effectiveness percentage of $88.89 \%$ (very good) of students who scored above 70 out of 10 test items. The value of $t$ count $>$ t table with the value of $t$ count $=2,13$ and $t$ table $=1,697$. So that the use of higher order thinking skills -based teaching materials can be said to be valid, practical and effective.
\end{abstract}

\begin{abstract}
Abstrak: Penelitian ini bertujuan untuk mengetahui hasil belajar siswa kelas XI di SMA Negeri Tugumulyo Tahun Pelajaran 2018/2019 setelah menggunakan buku ajar Fisika berbasis higher order thinking skills materi elastisitas dan hukum hooke dan untuk mengetahui respon siswa terhadap pembelajaran menggunakan pendekatan higher order thinking skills materi elastisitas dan hukum hooke siswa kelas XI di SMA Negeri Tugumulyo Tahun Pelajaran 2018/2019. Populasi penelitian ini adalah seluruh siswa kelas XI dan subjek penelitian ini terdiri dari 34 siswa kelas XI IPA 5 SMA Negeri Tugumulyo. Pengumpulan data dilakukan dengan teknik angket, tes, dan observasi. Persentase respon siswa terhadap buku ajar berbasis Higher Order Thinking Skills (HOTS) yaitu 76,53\% (sangat baik). Selain itu dari hasil tes ulangan harian memiliki persentase keefektifan 82,35\% (sangat baik) siswa yang memperoleh nilai di atas 62 dari 8 butir soal tes. Nilai $t_{\text {hitung }}>t_{\text {tabel }}$ dengan nilai dimana $t_{\text {hitung }}=2,13$ dan $t_{\text {tabel }}=1,697$. Sehingga penggunaan buku ajar berbasis Higher Order Thinking Skills (HOTS) dapat dikatakan valid, praktis dan efektif.
\end{abstract}

(C) 2019 Physics Education Department, STKIP PGRI Lubuklinggau, Indonesia

Kata kunci : Efektivitas, Buku Ajar Elastisitas dan Hukum Hooke, Higher Order Thinking Skills.

\section{PENDAHULUAN}

Pendidikan adalah proses untuk memberikan manusia berbagai macam situasi yang bertujuan memberdayakan diri. Perubahan dan perkembangan aspek pendidikan perlu ditunjang oleh kinerja pendidikan yang bermutu tinggi.
Pendidikan yang berkualitas sangat diperlukan guna mendukung terciptanya sumber daya manusia berkualitas serta mampu bersaing di era globalisasi. Pendidikan memegang peranan yang sangat penting dalam proses peningkatan kualitas sumberdaya manusia. 
Pemerintah telah membuat kurikulum yang fungsinya untuk meningkatkan mutu pendidikan bagi setiap siswa, memperbaiki sistem pengajaran dan pembelajaran yang ada di Negara kita ini. Dengan adanya perubahan kurikulum yang dilakukan oleh pemerintah, guru pun juga ikut serta membantu dalam peningkatan mutu siswa dengan berbagai cara. Salah satu nya dengan mengembangkan buku ajar bagi siswa. Selama ini buku ajar yang digunakan oleh pihak sekolah masih bersifat konvensional artinya buku ajar yang digunakan berasal dari pemerintah serta adapula dari pembelian eceran yang biasanya kita kenal dengan buku LKS.

Suwarni (2015:87) buku ajar merupakan salah satu buku yang menjadi acuan kegiatan belajar peserta didik. Buku ajar dapat membantu guru dalam menyampaikan materi pembelajaran, sehingga tujuan pembelajaran dapat tercapai. Dalam buku ajar seringkali kita menemukan adanya suatu penjelasan materi beserta hubungan-hubungan yang terkait dengan nya secara jelas. Seharusnya guru menciptakan suatu buku ajar dengan membantu siswa lebih bisa aktif dalam pembelajaran dengan membuat siswa merumuskan masalah dan membuat mereka menemukan sendiri jawaban dari masalah tersebut baik secara eksperimen, diskusi, ataupun praktikum agar lebih mudah memahami suatu materi/pelajaran karena mereka terlibat langsung dalam proses pemecahan masalah.

Salah satu buku ajar yang dikembangkan dalam mata pelajaran fisika adalah buku ajar berbasis Higher Order Thinking Skills (HOTS). Menurut Istiyono (2015: 106) bahwa Higher Order Thinking Skills (HOTS) merupakan proses berfikir yang tidak sekedar menghafal dan menyampaikan kembali informasi yang telah diketahui. Buku ajar berbasis Higher Order Thinking Skills (HOTS berisikan kemampuan menghubungkan, memanipulasi, dan mentransformasikan pengetahuan serta pengalaman yang sudah dimiliki untuk berfikir kritis dan kreatif dalam upaya menentukan keputusan dan memecahkan masalah pada situasi yang baru dan itu semua tidak dapat dilepaskan dari kehidupan seharihari.

Aspek-aspek dari kemampuan berfikir tingkat tinggi peserta didik pada khususnya fisika dapat ditinjau dari taksonomi Bloom. Dalam taksonomi Bloom terdapat tiga aspek dari ranah kognitif yang menjadi bagian dari kemampuan berfikir tingkat tinggi yaitu 
aspek analisis, aspek evaluasi, dan aspek mencipta.

\section{Penggunaan Higher Order Thinking} Skills (HOTS) sebagai salah satu pendekatan pembelajaran menghasilkan aktivitas belajar yang produktif khususnya dalam interaksi socio-cognitive, misalnya dalam hal: (1) memberi dan menerima bantuan; (2) mengubah dan melengkapi sumber informasi; (3) mengelaborasi dan menjelaskan konsep; (4) berbagi pengetahuan dengan teman; (5) saling memberi dan menerima balikan; (6) menyelesaikan tugas dalam bentuk kolaboratif, dan (7) berkontribusi dalam menghadapi tantangan. Serta dengan Higher Order Thinking Skills (HOTS) siswa akan belajar lebih mendalam, knowledge is the thick, siswa akan memahami konsep lebih baik. Penggunaan buku ajar ini membuat siswa bisa mengerti materi dengan mudah karena semua permasalahan yang dihadapi oleh siswa semuanya bisa diatasi sendiri oleh siswa

Berdasarkan pejelasan yang telah diuraikan dan beberapa permasalahan di atas, maka perlu dilaksanakan penelitian dengan judul "Efektivitas Buku ajar Fisika Berbasis Higher Order Thinking Skills Materi Elastisitas dan Hukum Hooke Siswa Kelas XI Di SMA Negeri
Tugumulyo Tahun Pelajaran 2018/2019”, maka tujuan dalam penelitian ini adalah sebagai berikut:

1. Untuk mengetahui hasil belajar siswa kelas XI di SMA Negeri Tugumulyo Tahun Pelajaran 2018/2019 setelah menggunakan buku ajar fisika berbasis higher order thinking skills materi elastisitas dan hukum hooke.

2. Untuk mengetahui respon siswa terhadap pembelajaran menggunakan pendekatan higher order thinking skills materi elastisitas dan hukum hooke siswa kelas XI di SMA Negeri Tugumulyo Tahun Pelajaran 2018/2019.

\section{LANDASAN TEORI}

\section{Efektivitas Pembelajaran}

Trianto (2009:20) menyatakan bahwa suatu pembelajaran dikatakan efektif apabila memenuhi persyaratan utama keefektifan pengajaran, yaitu:

a. Presentasi waktu belajar siswa yang tinggi dicurahkan terhadap KBM;

b. Rata-rata perilaku melaksanakan tugas yang tinggi di antara siswa;

c. Ketetapan antara kandungan materi ajaran dengan kemampuan siswa (orientasi keberhasilan belajar) diutamakan; dan 
d. Mengembangkan suasana belajar yang akrab dan positif, mengembangkan struktur kelas yang mendukung butir (2), tanpa mengabaikan butir (4).

Nurfaidah, dkk $(2017: 112)$ menyatakan bahwa siswa dikatakan tuntas belajar secara individu jika presentase daya serap individu $>65 \%$. Sedangkan suatu kelas dinyatakan tuntas belajar secara klasikal jika > 80\% siswa yang telah tuntas. Jadi pembelajaran menggunakan buku ajar fisika berbasis higher order thinking skills efektif terhadap hasil belajar siswa dilihat dari ketuntasan belajar, pembelajaran dapat dikatakan tuntas apabila > 80\% dari jumlah siswa yang telah belajar dapat memperoleh nilai $\geq 62$.

Berdasarkan beberapa pendapat di atas, maka dapat disimpulkan efektivitas pembelajaran merupakan suatu usaha atau strategi yang melibatkan seluruh komponen pendidikan dalam mencapai tujuan pendidikan yang telah ditetapkan sebelumnya secara tepat. Berkaitan dengan terlaksananya semua tugas pokok, tercapainya tujuan, ketepatan waktu, adanya partisipasi aktif dari anggota. Efektivitas dalam pembelajaran ini adalah hasil belajar mencapai ketuntasan KKM $\geq 62$ dengan presentase ketuntasan $>80 \%$ dan respon siswa terhadap penggunaan model pembelajaran higher order thinking skills baik.

\section{Hasil Belajar}

Kasmadi dan Sunariah (2013:44) menyatakan bahwa hasil belajar adalah perubahan perilaku yang diperoleh siswa setelah melakukan kegiatan belajar. Terjadinya peubahan perilaku tersebut dapat diamati dan diukur dalam bentuk perubahan pengetahuan siswa sebagai hasil belajar dan proses interaksi dengan lingkungannya yang diwujudkan melalui pencapaian hasil belajar.

Dimyanti dan Mudjiono (2006:26) menyatakan bahwa siswa yang belajar berarti menggunakan kemampuan kognitif, afektif, dan psikomotorik terhadap lingkungannya. Adapun hasil belajar yang diukur dalam penelitian ini adalah pada ranah kognitif, afektif, dan psikomotorik.

\section{Respon Siswa dalam Pembelajaran dengan Higher Order thinking Skills}

Hamalik (dalam Baroh, 2010:36), respon merupakan gerakan-gerakan yang terkoordinasi oleh persepsi seseorang terhadap peristiwa luar dalam lingkungan sekitar. Marsiyah (dalam baroh, 2010:36) untuk mengetahui respon seseorang terhadap sesuatudapat melalui angket, karena angket pada umumnya meminta keterangan tentang fakta yang diketahui 
oleh responden/yang mengenai pendapat atau sikapnya.

Baroh (2010:36) menyatakan bahwa indikator respon siswa yang akan dideskripsikannya meliputi:

a. Sikap siswa terhadap pelajaran fisika

b. Respon siswa terhadap cara guru mengajar

c. Respon siswa terhadap cara belajar fisika

d. Respon siswa terhadap proses pembelajaran dengan model pembelajaran

e. Sikap siswa terhadap fisika setelah mengikuti pembelajaran fisika dengan menggunakan model pembelajaran

Adapun indikator respon siswa yang ada dalam penelitian ini ditunjukkan dalam tabel 1.

Tabel 1. Indikator Respon Siswa dalam Pembelajaran dengan Pendekatan Scientific

\begin{tabular}{|c|c|c|}
\hline No & Aspek & Indikator \\
\hline 1. & $\begin{array}{l}\text { Sikap siswa } \\
\text { terhadap } \\
\text { pelajaran fisika }\end{array}$ & $\begin{array}{l}\text { a. } \text { Menunjukkan } \\
\text { minat terhadap } \\
\text { pelajaran fisika } \\
\text { b. } \\
\text { Menunjukkan } \\
\text { manfaat } \\
\text { mempelajari fisika }\end{array}$ \\
\hline 2. & $\begin{array}{l}\text { Sikap siswa } \\
\text { terhadap } \\
\text { pembelajaran } \\
\text { dengan }\end{array}$ & $\begin{array}{l}\text { a. Menunjukkan } \\
\text { minat terhadap } \\
\text { pelajaran fisika } \\
\text { dengan }\end{array}$ \\
\hline
\end{tabular}

\begin{tabular}{cc}
\hline $\begin{array}{c}\text { menggunakan } \\
\text { Pendekatan }\end{array}$ & $\begin{array}{l}\text { pendekatan } \\
\text { Scientific }\end{array}$ \\
b. Menunjic \\
manfaat mengikuti \\
pembelajaran \\
fisika dengan \\
Pendekatan \\
Scientific \\
Modifikasi Baroh (2010:36) \\
Berdasarkan beberapa pendapat diatas, \\
maka respon siswa didefinisikan sebagai \\
tanggapan dari siswa pada saat kegiatan \\
pembelajaran berlangsung. Respon siswa \\
tersebut dapat kita ketahui melalui angket \\
atau kuesioner yang kita berikan kepada \\
siswa yang telah mengikuti kegiatan \\
pembelajaran.
\end{tabular}

5. Higher Order Thinking Skills (HOTS)

Istiyono (2015:106) menyatakan bahwa Higher Order Thinking Skills (HOTS) merupakan kemampuan menghubungkan, memanipulasi, dan mentransformasi pengetahuan serta pengalaman yang sudah dimiliki untuk berpikir secara kritis dan kreatif dalam upaya menentukan keputusan dan memecahkan masalah pada situasi yang baru dan itu semua tidak dapat dilepaskan dari kehidupan sehari-hari. Berpikir tingkat tinggi terjadi ketika seseorang menerima informasi baru dan mengambil informasi yang tersimpan dalam memori lalu saling menghubungkan atau menata 
kembali dan memperluas informasi untuk mencapai tujuan seperti menemukan jawaban atas persoalan yang dihadapi. Sedangkan menurut Saputra (dalam Supranoto, 2018: 105) Higher Order Thinking Skill (HOTS) adalah kemampuan berpikir kritis, logis, reflektif, metakognitif, dan berpikir kreatif yang merupakan kemampuan berpikir tingkat tinggi.

\section{METODOLOGI PENELITIAN}

Dalam metode penelitian menggunakan teknik pengumpulan data dan teknik analisis data sebagai berikut:

\section{Teknik Pengumpulan Data}

\section{a. Observasi}

Sudijono (2015:76) menyatakan bahwa observasi sebagai alat evaluasi banyak digunakan untuk menilai tingkah laku individu atau proses terjadinya suatu kegiatan yang dapar diamati, baik dalam situasi yang sebenarnya maupun dalam situasi buatan.

b. Angket atau Kuesioner

Arikunto (2013:194) menyatakan bahwa kuesioner adalah sejumlah pertanyaan tertulis yang digunakan untuk memperoleh informasi dari responden dalam arti laporan tentang pribadinya, atau hal-hal yang ia ketahui.

c. Buku ajar HOTS
Perangkat pembelajaran yang dikembangkan dalam penelitian ini adalah Buku ajar Fisika Berbasis higher order thinking skills. Pertanyaan-pertanyaan yang tercantum dalam buku ajar digunakan untuk mengukur ketercapaian hasil belajar siswa.

d. Tes

Instrumennya berupa soal tes, menurut Arikunto (2013:193) menyatakan tes adalah serentetan pertanyaan atau latihan serta alat lain yang digunakan untuk mengukur keterampilan, pengetahuan inteligensi, kemampuan atau bakat yang dimiliki oleh individu atau kelompok.

\section{Teknik Analisis Data}

Gunawan (2014:210) menyatakan bahwa teknik pengumpulan data dan analisis data pada praktiknya tidak secara mudah dipisahkan. Kedua kegiatan tersebut berjalan serempak. Artinya analisis data memang seharusnya dikerjakan bersamaan dengan pengumpulan data, dan kemudian dilanjutkan setelah pengumpulan data selesai dikerjakan. Teknik analisis yang digunakan yaitu deskriptif kuantitatif untuk mengetahui kelayakan dan respon siswa terhadap Buku ajar Fisika Berbasis higher order thinking skills yang dikembangkan keterampilan proses siswa, 
dan analisis ketercapaian hasil belajar kognitif.

a. Analisis Respon Siswa Terhadap Buku ajar

Teknik analisis data untuk respon siswa terhadap Buku ajar Fisika Berbasis higher order thinking skills, dilakukan dengan menganalisis angket/kuesioner yang diberikan peneliti. Lembar angket kelayakan buku ajar tersebut direkam menggunakan instrumen lembar uji coba.

Jawaban setiap item instrumen yang menggunakan skala likert mempunyai gradasi dari sangat positif sampai sangat negatif. Penetapan skor untuk pertanyaan positif dan negatif adalah kebalikan seperti tampak pada tabel 2.

Tabel 2. Penetapan skor skala likert

\begin{tabular}{ccccc}
\hline $\begin{array}{c}\text { Pernyataan } \\
\text { Sikap }\end{array}$ & SS & S & TS & STS \\
\hline $\begin{array}{c}\text { Pernyataan } \\
\text { Positif }\end{array}$ & 4 & 3 & 2 & 1 \\
$\begin{array}{c}\text { Pernyataan } \\
\text { Negatif }\end{array}$ & 1 & 2 & 3 & 4 \\
\hline
\end{tabular}

Skor maksimal skala bagi suatu sikap unit analisis adalah jumlah item dalam skala sikap dikalikan dengan 4 diberi simbol 4K, sedangkan minimalnya adalah jumlah item dalam skala sikap dikalikan 1 diberi simbol $\mathrm{K}$, jadi rentang skor teoritik skala sikap adalah K-4K. Sugiyono (2012:137) menyatakan bahwa skor yang telah ditetapkan dapat dihitung sebagai berikut:

Persentase $=\frac{\text { skor yang diperoleh }}{\text { skor maksimum }} \times 100 \%$

b. Analisis Ketercapaian Hasil Belajar Kognitif

Ketercapaian hasil belajar siswa dalam pembelajaran fisika menggunakan buku ajar berbasisi higher order thinking skills dilihat dari skor akumulasi (skor akhir) yang diperoleh setiap siswa dalam mengerjakan soal-soal yang telah disiapkan dalam lembar kegiatan siswa. Data dianalisis menggunakan uji hipotesis. Sugiyono

(2012:96) menyatakan bahwa hipotesis merupakan jawaban sementara terhadap rumusan masalah, dimana rumusan masalah penelitian telah dinyatakan dalam bentuk kalimat pertanyaan. Arief, dkk (2017:148) hipotesis adalah pernyataan dugaan tentang hubungan antara dua variabel atau lebih.

Sugiyono (2007: 96), Uji hipotesis menggunakan uji t, dinyatakan sebagai berikut:

$\mathrm{t}=\frac{\bar{x}-\mu_{0}}{\frac{s}{\sqrt{n}}}$

Dimana, $\mathrm{t}$ adalah nilai yang dihitung, $\bar{x}$ adalah nilai rata-rata, $\mathrm{n}$ adalah jumlah anggota sampel, $\mu_{0}$ adalah nilai yang hipotesisnya $\left(\mu_{0}=62\right)$. Hipotesis yang diujikan adalah sebagai berikut: 
$\mathrm{H}_{\mathrm{a}}$ : rata-rata nilai hasil belajar kognitif siswa setelah mengikuti pembelajaran fisika menggunakan buku ajar fisika berbasis higher order thinking skills lebih dari atau sama dengan 62 . $\left(\mathrm{H}_{\mathrm{a}}: \mu_{0} \geq 62\right)$

$\mathrm{H}_{0}$ : rata-rata nilai hasil belajar kognitif siswa setelah mengikuti pembelajaran fisika menggunakan buku ajar fisika berbasis higher order thinking skills kurang dari 62. $\left(\mathrm{H}_{\mathrm{a}}\right.$ : $\mu_{0}<62$ )

Dimana kriteria pujiannya adalah jika $t_{\text {hitung }} \geq \mathrm{t}_{\text {tabel }}$ maka $\mathrm{H}_{0}$ ditolak dan $\mathrm{H}_{\mathrm{a}}$ diterima dan jika $t_{\text {hitung }}<t_{\text {tabel }}$ maka $\mathrm{H}_{0}$ diterima dan $\mathrm{H}_{\mathrm{a}}$ ditolak. Dengan derajat kebebasan $(\mathrm{dk})=\mathrm{n}-1$ dengan taraf kesalahan $(\alpha)=5 \%$.

\section{HASIL DAN PEMBAHASAN}

\section{Hasil Penelitian}

Penelitian dilakukan pada siswa kelas XI IPA 5 di SMA Negeri Tugumulyo yang dilaksanakan pada hari selasa dan jum'at dari tanggal 04 September 2018 sampai 18 September 2018 yang melibatkan 34 siswa, tediri atas 12 siswa laki-laki dan 22 siswa perempuan.

Berdasarkan hasil penelitian dapat disimpulkan bahwa buku ajar fisika berbasis higher order thinking skills menunjukkan penilaian yang sangat baik. Oleh karena itu, buku ajar fisika berbasis higher order thinking skills dapat dikatakan praktis dan dapat digunakan.

Tahapan akhir dari penelitian ini adalah untuk melihat keefektifan buku ajar fisika berbasis higher order thinking skills. Keefektifan tersebut dapat dilihat dari hasil belajar siswa dalam ranah kognitif serta respon siswa terhadap pembelajaran menggunakan pendekatan higher order thinking skills.

Dalam ranah kognitif yang dinilai yaitu nilai tes siswa setelah mengunakan buku ajar fisika berbasis higher order thinking skills. Hal ini dilakukan untuk melihat keefektifan buku ajar berbasis higher order thinking skills materi elastisitas dan hukum hooke dari hasil belajar siswa. Uji coba hasil belajar dalam ranah kognitif dilakukan untuk mengetahui tingkat kemampuan siswa setelah menggunakan buku ajar berbasis higher order thinking skills. Tes ini dilaksanakan setelah selesainya proses kegiatan belajar mengajar, siswa diberikan waktu selama dua jam pelajaran untuk menyelesaikan soal tes. Berdasarkan kriteria hasil tes ulangan harian siswa dapat dicapai dengan baik atau efektif apabila mendapat nilai akhir $\geq 62$. 
Setelah diadakan pelaksanaan tes yang mengikuti tes ulangan harian ada 34 siswa. Terdapat 28 siswa yang nilainya di atas skor 62 dapat dinyatakan tuntas, dan 6 siswa yang nilainya belum mencapai skor diatas 62 tidak dapat dinyatakan tuntas. Dengan demikian buku ajar berbasis higher order thinking skills sudah dapat dikatakan efektif dengan ketuntasan efektivitas pembelajaran secara klasikal sebesar 82,35\%. Respon siswa terhadap pembelajaran dilakukan dengan tujuan untuk melihat keefektifan buku ajar fisika berbasis higher order thinking skills. Untuk mengetahui hal tersebut peneliti memberikan angket tertutup kepada siswa dengan 20 butir pernyataan. Angket ini diberikan setelah seluruh proses pembelajaran selesai. Hasil angket respon siswa secara keseluruhan terhadap pembelajaran dengan pendekatan higher order thinking skills terbilang sangat baik dengan persentase $56,50 \%$, siswa yang sangat setuju jika buku tersebut sangat praktis digunakan dalam pembelajaran persentasenya mencapai $27,38 \%$ dan siswa yang tidak setuju persentasenya mencapai $1,25 \%$, sedangkan sangat tidak setuju tidak ada siswa yang memiliki pernyataan tersebut. Hasil persentase respon siswa pada uji coba kelompok luas dengan menggunakan angket dapat dijabarkan pada gambar diagram berikut.

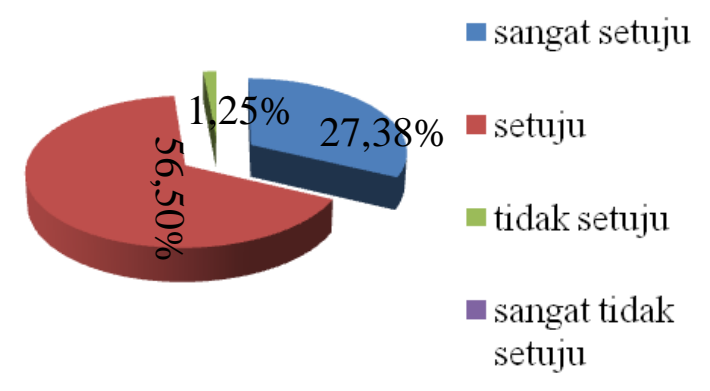

Gambar 1. Diagram Hasil Respon Siswa

Hal ini menunjukkan respon yang sangat baik terhadap pembelajaran dengan pendekatan higher order thinking skills siswa kelas XI IPA 5 di SMA Negeri Tugumulyo tahun pelajaran 2018/2019.

\section{Pembahasan}

Tujuan penelitian ini untuk melihat keefektifan hasil belajar setelah diterapkannya buku ajar fisika berbasis higher order thinking skills materi elastisitas dan hukum hooke yang valid, praktis, dan efektif. Buku ajar fiska berbasis higher order thinking skills adalah buku yang di dalamnya memuat tiga komponen higher order thinking skills yaitu menganalisis, mengevaluasi dan mencipta. Dengan demikian siswa dapat tertarik untuk mengikuti proses pembelajaran. Penelitian ini dilaksanakan pada tanggal 31 Agustus 2018 sampai 18 September 2018 di SMA Negeri Tugumulyo. 
Setelah melakukan wawancara dengan guru mata pelajaran fisika kelas XI diketahui bahwa kemampuan siswa relatif sama sehingga peneliti langsung memilih sesuai dengan tujuan dan kebutuhan peneliti, kelas yang dipilih untuk uji coba kelompok luas adalah kelas XI IPA 5 sebagai sampel penelitian diberikan perlakuan pembelajaran dengan buku ajar berbasis higher order thinking skills dengan demikian sampel penelitian ini berjumlah 34 siswa.

Selanjutnya keefektifan buku ajar berbasis higher order thinking skills dapat dilihat dari nilai hasil tes ulangan harian, serta respon siswa terhadap pembelajaran. Nilai siswa dikatakan baik apabila mendapatkan nilai dari hasil tes ulangan harian $\geq 62$. Rata-rata nilai tes ulangan harian kelas XI IPA 5 SMA Negeri Tugumulyo pada tahap uji coba kelompok luas yang berjumlah 34 siswa adalah 68,5 dimana 28 siswa yang mendapatkan nilai di atas 62 artinya 28 siswa tuntas dan 6 siswa mendapat nilai di bawah 62 artinya 3 tidak tuntas. Maka, 82,35\% yang telah berhasil menggunakan buku ajar berbasis higher order thinking skills dengan baik. Dengan demikian, buku ajar berbasis higher order thinking skills telah efektif digunakan di kelas XI IPA 5 SMA Negeri Tugumulyo. Berdasarkan hasil tersebut maka didapatkan bahwa uji hipotesis satu pihak dalam penelitian ini dengan derajat kebebasan 0,05 diperoleh $t_{\text {hitung }}=2,13$ dan $t_{\text {tabel }}=1,697$ karena $t_{\text {hitung }}>t_{\text {tabel }}$ maka $H_{a}$ diterima dan $\mathrm{H}_{0}$ ditolak. Persentase respon siswa terhadap pembelajaran menggunakan pendekatan higher order thinking skills yaitu $76,53 \%$ tergolong kategori sangat baik. Artinya buku ajar berbasis higher order thinking skills sudah terbilang efektif untuk digunakan. Dengan demikian, buku ajar berbasis higher order thinking skills sudah valid, praktis, dan efektif.

\section{SIMPULAN DAN SARAN}

Berdasarkan hasil penelitian, peneliti menyimpulkan bahwa:

1. Buku ajar berbasis higher order thinking skills dibuat untuk mengetahui efektivitas penggunaan buku ajar terhadap hasil belajar siswa dan untuk mengetahui respon siswa setelah menggunakan pembelajaran dengan pendekatan higher order thinking skills.

2. Presentase keseluruhan repon siswa terhadap buku ajar berbasis Higher Order Thinking Skills (HOTS) adalah $76,53 \%$ sehingga buku ajar dikatakan praktis dan memenuhi kriteria sangat setuju atau positif. Hasil penilaian 
keefektifan terhadap buku ajar berbasis Higher Order thinking skills (HOTS) pada presentase hasil tes ulangan harian sebesar $82,35 \%$ siswa yang memperoleh nilai di atas 62 ada 28 siswa dan 6 siswa nilainya dibawah 62 dari 8 butir soal tes sehingga buku ajar dikatakan efektif. Dimana nilai rata-rata yang didapat berupa, thitung $=2,13$ dan ttabel $=1,697$, karena thitung $\geq_{\text {ttabel }}$. Sehingga dapat dikatakan на diterima dan но ditolak karena rata-rata nilai hasil ulangan siswa kelas XI IPA 5 adalah 68,5 yang nilainya $>62$. Oleh karena itu, buku ajar berbasis Higher Order thinking skills (HOTS) materi Elastisitas dan Hukum Hooke dapat dikatakan valid, praktis dan efektif.

Adapun saran pemanfaatan dan pengembangan produk lebih lanjut adalah sebagai berikut:

1. Penulis menyarankan buku ajar berbasis Higher Order thinking skills dapat digunakan dalam pembelajaran materi elastisitas dan hukum hooke karena telah mendapat penilaian sangat baik dan layak digunakan.

2. Buku ajar berbasis Higher Order thinking skills bisa dikolaborasikan dengan model pembelajaran yang lain
3. Penulis menyarankan buku ajar berbasis Higher Order thinking skills dapat membantu guru dalam menyampaikan materi.

\section{DAFTAR PUSTAKA}

Arif, dkk. 2017. Pengaruh Kepercayaan Merek Dan Komitmen Merek Terhadap Loyalitas Merek (Survei pada Warga Kelurahan Penanggungan Konsumen Produk Aqua di Kota Malang). Jurnal Administrasi Bisnis (JAB). 44 (1), hal 148.

Arikunto, Suharsimi. 2013. Prosedur Penelitian. Jakarta: Rineka Cipta.

Baroh, Chasniatul. 2010. Efektivitas Metode Simulasi dalam Pembelajaran Matematika pada Pokok Bahasan Peluang di Kelas IX-A MTs Nurul Huda Kalanganyar Sedati Sidoarjo. Skripsi Pendidikan Matematika.

Dimyanti \& Mudjiono. 2006. Belajar dan

Pembelajaran. Jakarta: Rineka Cipta.

Gunawan, Imam. 2014. Metode Penelitian Kualitatif. Jakarta: Bumi Aksara.

Istiyono, dkk. 2015. Studi Pelaksanaan Pembelajaran Fisika Berbasis Higher Order Thinking Skills (HOTS) Pada 
Kelas X SMA Negeri Kota

Yogyakarta. Prosiding Seminar

Nasional Fisika dan Pendidikan

Fisika (SNPF)Ke-6 (1).

Kasmadi \& Nia Siti Sunariah. 2013.

Panduan Modern Penelitian

Kuantitatif. Bandung: Alfabeta.

Sudijono, Anas. 2015. Pengantar

Evaluasi Pendidikan. Jakarta:

Rajawali Pers.

Sugiyono. 2007. Statistika Untuk

Penelitian. Bandung: CV Alfabeta.

Sugiyono. 2012. Metode Penelitian

Pendidikan. Bandung: Alfabeta.

Supranoto, Heri. 2018. Pengembangan

Soal HOTS Berbasis Permainan

Ular Tangga Pada Mata Kuliah

Telaah Ekonomi SMA. Jurnal

Pendidikan Ekonomi UM Metro. 6

(1), hal 105.

Suwarni, Erna. 2015. Pengembangan

Buku Ajar Berbasis Lokal Materi

Keanekaragaman Laba-Laba Di

Kota Metro Sebagai Sumber Belajar

Alternatif Biologi Untuk Siswa

SMA kelas X. Jurnal Pendidikan

Biologi. 6 (2), hal 87.

Trianto. 2009. Mendesain Model

Pembelajaran Inovatif-Progresif.

Jakarta: Kencana. 